\title{
EFL Teachers' Emotion Regulation in Response to Online-Teaching at Van Lang University
}

\author{
Thuy, Ngo Thi Cam ${ }^{1 *}$ \\ ${ }^{1}$ Van Lang University, Ho Chi Minh City \\ * Corresponding author. Email: thuy.ntc@vlu.edu.vn
}

\begin{abstract}
The increasing expansion of the Covid-19 pandemic has put most social and economic activities to change their business style for a sustainable existence; education is not an exception. Online learning environments (OLEs) have become the field for academic researchers to work on, from pedagogical theories to teaching-and-learning activities. However, very few studies on teachers' emotions have been conducted. The current research has been carried out to identify the types of emotions that EFL teachers feel, the factors that influence these emotions, and how they regulate challenging emotions in online-teaching at Van Lang University. A qualitative was conducted with six instructors (ranging from novice to 15-years experienced teachers) teaching in different OLEs formats (Microsoft Team, Edusoft, Zoom, Google classroom, and E-learning). Five emotions linked to online teaching were identified: feeling restricted, stressed, devalued, validated, and rejuvenated. The practical implications of these results are discussed.
\end{abstract}

Keywords: EFL teachers' emotions, online-teaching, OLEs.

\section{INTRODUCTION}

In the industry 4.0 era, one of the most promising trends for the development of modern education is distance learning, in particular, online learning on the basis of modern information technologies, which meets all the requirements of the new educational paradigm of the information society, such as mass education for all population categories regardless of their place of residence, especially, open, personoriented and lifelong learning of people throughout their life.

Since the beginning of the COVID-19 pandemic, April 2020, the International Association of Universities and UNESCO (2020) have reported that over 1.5 billion students from 185 countries suffer from disrupting their regular learning practices of university closures. Particularly, two-thirds of these students have transferred from face-to-face learning to online-learning due to temporary solutions for keeping the academic curriculum on track. The higher education in Vietnam also shares a similar disruption when the Ministry of Education and Training (MOET) made a stipulation of 'suspending school, not stopping learning' from the beginning of the Covid-19 outburst. This resulted in 110/240 universities and colleges in Vietnam kept on with the planned curriculum by adapting online-teaching platforms, such as Microsoft Teams, Google Classroom, and Zoom, with private institutions making up $70 \%$ [22]. In order to support teachers with their online classes, online training workshops were provided with the participation of both national and international experts on onlineteaching.

Over the last couple of decades, there has been an increasing trend in researching students' perceptions of participating in online courses [36], making a comparison between face-to-face and online-teaching models [4], and observing the interaction between teachers and students both inside and outside class [35]. Students' emotions in online-learning were especially found more negative with loneliness, isolation, and anxiety, which needs more research for promoting connectedness [20,26,40].

Although this changing teaching format presents various challenges and concerns to many instructors, less is researched about instructors' emotions in OLEs $[5,35]$. In the effort of researching the aspects of online-teaching, it is believed that this "new form of pedagogy" is different from traditional teaching models, including the mode for organizing teaching tasks, providing feedback, motivating, and reinforcing students [29,31]. This trendy academic working style 
has left instructors, especially EFL teachers, more negative than positive ones.

The article aims at exploring the emotions that EFL teachers experience at different stages of the first 10week semester applying online teaching because of social lockdown during the COVID-19 pandemic. The research also explores how EFL teachers regulate their negative emotions to adapt themselves professionally to the changing social states, which is a part of the definition of 'good' professional performance [36].

\section{LIERATURE REVIEW}

\subsection{Emotions in EFL teaching}

The beginning of 2010 witnessed the appearance of studies about teachers' emotions in the language teaching field [6], which attracted applied linguists or language teacher-researchers working on EFL teachers' emotions [38,32]. Barcelos and Ruohotie-Lyhty [2] pointed out two aspects that are worth considering in these previous studies. First, emotions play a crucial role in shaping what teaches do in class and their relationships with people at work, including colleagues, students, and the profession itself. Second, more research should be a focus on what teachers "do" than what they are [24].

\subsection{Emotions involved in online-teaching in higher education}

Teachers' emotions involved in teaching at the university level have been positive and negative, including inspiration, humiliation, anger, anxiety, and pride [34]. In their research, Löfström and Nevgi[19] used a system of classification for emotional teaching responses comprised of three categories: positive, neutral, and negative. More recently, Badia et al.[1] defined a three-factor structure of emotions regarding teaching in higher education, using an exploratory factor analysis based on a differential methodology, which was considered effective dimensions of teaching, namely motivation for teaching, assessment of oneself as a teacher, and achievement in teaching.

Nevertheless, few research studies on the emotions involved in teaching online at the university level have been performed. In a report on online teaching, Wickersham and McElhany [37] pointed out that online instructors have different concerns about the quality of online teaching, such as the amount of time taken to design and create an online course, the potential lack of social interaction during the course, the fear of the popularity of online courses with administrators, the lack of technical training for students, and their ability to communicate with administrators. Regan et al.[25] pointed out that some of the feelings encountered by teachers were negative, like feeling limited (technology limits how they can teach), anxious (frustrated or uncertain), and devalued (helpless and insecure). However, some optimistic emotions, such as validated (pleased, proud, satisfied) and rejuvenated (pleased, proud, satisfied) emotions, are undeniable (convenient, intrigued, and liberated). It was also found that there is a risk of their selfesteem being fragile in virtual learning environments as online instructors switch from a student-centered learning environment to a direct educational approach [27].

\subsection{Emotion Regulation}

The capacity to regulate the perception and expression of emotions [9] is a clear concept of emotion regulation. Researchers have come to realize in recent studies that emotion control has a valuable role in teaching practices. Emotion management makes it possible for educators to influence their behavior[21] and stay active with the environment. The regulation also helps educators to prevent negative emotions and develop positive emotions. The use of emotion management strategies will sustain individual wellbeing and enhance interpersonal functioning[10]. Therefore, techniques for emotion management would also positively affect teachers' professional lives and encourage the development of teaching.

\subsection{Theoretical Framework}

Gross and Thompson [11] proposed a model for emotion regulation considering emotions as multicomponential [28] and the generative emotion cycle [17]. The process model of emotion regulation describes five families of emotion regulation strategies linked to controlling emotions either before (antecedent-centered emotion regulation) or after (response-focused emotion regulation). Individuals may choose to use situation selection, situation adjustment, deployment of attention, or cognitive change as resources for background-focused emotion regulation, or response modulation as a responsefocused way to manage their emotions [12]. There is a bidirectional relationship between emotion control and emotion in the emotion regulation process model: while situation adjustment can alter emotional responses, emotional responses can also alter situations. For example, a teacher who alters disruptive students' seating arrangement can decrease the irritation caused by them, or a teacher who frowns prompts students' disruptive behaviors to decrease. In addition, teachers may up-regulate or down-regulate their emotions during teaching time. 


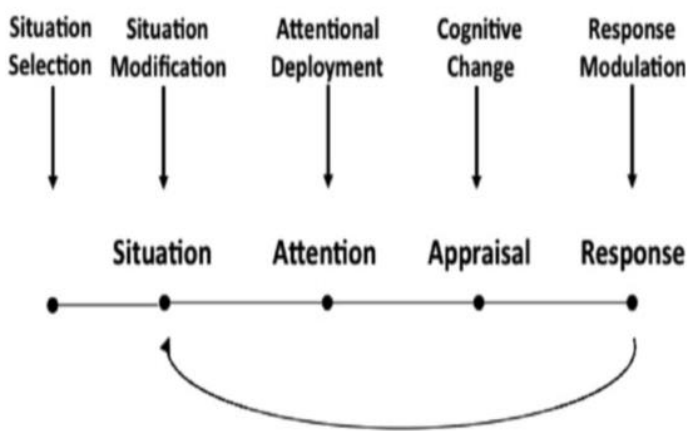

The emotion control process model was derived by defining each of the key points in the modal model where the emotion-generative process could be altered. (Gross, 1998)

In general, teachers up-regulate their positive emotions to increase their intensity and duration and to communicate positively with their students. They down-regulate negative emotions for classroom management purposes and continue positive interactions with students $[8,33]$.

\subsection{Aim of the study}

This study seeks to understand how EFL teachers in a private university perceive and experience their emotions, both negative and positive, as they transitioned to online teaching and what strategies they employ to manage the negative ones. The study also sheds light on the influence of emotions on educators' pedagogical methods and professional growth and how emotions play out in the university's online environment.

This research might be significant in the way it raises educational policies' attention in terms of providing more technology-related training programs to EFL teachers. Moreover, it would contribute to developing EFL teachers' skills in using educational, technological devices in classrooms.

Two research questions were raised with this purpose in mind:

1. What kinds of emotions that EFL teachers experience when applying full online-teaching during the 10-week semester at Van Lang university?

2. How do EFL teachers regulate their emotions in response to online-teaching at Van Lang university?

\section{METHOD}

\subsection{Context of the Study}

Since the Covid-19 outburst occurred at the same time, beginning the Spring Semester in Van Lang
University, most of the academic courses were required to change from the regular face-to-face teaching-learning courses to online-teaching. Luckily, some teachers who have been rather familiar with blended teaching methods felt rather comfortable keeping track of the planned curriculum. To support teachers with technological practice, the university has supplied various online training courses and instant guides to help both teachers and students get along well with the newly full-time online course. However, some teachers are still working on the changing teaching method with reluctance and inconvenience, which can cause more or less ineffective impacts on students' academic performance and results.

\subsection{Participants}

This study's data were collected from EFL teachers at VLU in the Spring semester. The participants were six EFL teachers, including four males and two females, and one of them was enrolled in a Ph.D. program in English Language Teaching. Those teachers were of different ages, genders, and teaching experience. In terms of professional orientation, the selection criteria were somewhat different, assuming that teachers will often vary in their emotions relevant to current reforms and explicitly explain how they interpret and assess current reforms. The emphasis was not only on the basic feelings but also on the way the teachers assessed the challenges and the situational criteria they faced with the new demanding OLEs. Participants differed in their level of familiarity with the technical side of teaching in OLEs. All six participants referred to the use of Blackboard, two to Skype, five directly to MS Teams, Zoom, and four to specific channels for data sharing such as Google Docs and Google Classroom.

\subsection{Procedure}

The current study explored the kinds of emotions that EFL teachers feel when implementing online teaching practices. Additionally, it examined the extent to which online-teaching changed EFL teacher's identity in the way they regulate their negative emotions. Therefore, the researcher designed the present research approach based on a qualitative method that permits for a deeper understanding of the participants in particular phenomena [3]. The qualitative approach encompasses a semi-structured interview used to collect deeper insights into the participants' emotions, thoughts, and actions [3]. The participants responded to the interview questions in the Faculty of Foreign Languages at Van Lang University; the answers were all recorded. The interview consisted of two parts: the first, it was related to the general information (such as gender, age, teaching experience, teaching method, and training program regarding E-learning). The second included semi-structured interviews collected together after considering the factors that affected EFL teachers' emotions while applying online-teaching. 
The participants then discussed how the identified emotions elicited specific actions of teaching in OLEs, how they adjusted their teaching, and/or how the more challenging emotions were regulated. Specifically, the questions brought to the research the discussion of both successful and unsuccessful attempts used to navigate and/or cope through the established emotions when instructing in OLEs.

\subsection{Data Collection Procedure and Analysis}

The six teachers were interviewed at the end of the Spring Semester when they had just finished the firsttime online-teaching course, and the real emotions are still impressed. The interviews took place either at school or at home. The researcher conducted each of the interviews; at the conclusion of the interview, she asked questions with the help of a subject list, listened, took notes, and probably posed additional questions. These tasks' goal was to promote the recall of one's experience and think about teaching in OLEs specifically. Participants will better define their behaviors and decisions when teaching by enabling participants first to think and then communicate their feelings[18]. The decision to use Vietnamese in all these interactions was crucial because - even though the participants were teachers of English - it was considered that using their first, rather than a second, language would enable the participants to express themselves more thoughtfully and clearly and would be probably less threatening and easier for them to do so. This latter point is extremely important, as this was the first time the participants had been asked to carry out this nature task.

\section{FINDING AND DISCUSSION}

In the first research question, "What kinds of emotions that EFL teachers experience when applying full online-teaching during the 10-week semester at Van Lang University?" the researcher focused on highlighting the emotions that EFL teachers felt when they unexpectedly became firsttime online teachers because of social lockdown during Covid-19 pandemic. Take the stages of a culture shock into account. An EFL teacher experiencing the changing teaching method under socio-cultural impacts is also believed to follow a similar sequence, including The Honey Moon period, Troubles in Paradise, and the Road Recovery [7]. Both negative and positive emotions reported in the semiinterviews could be grouped into five themes: feeling restricted, stressed, devalued, validated, and rejuvenated.

\subsection{Stage 1: The Honey Moon period}

In this stage, the emotion from the first impression of something new and highly qualified moves from what might have been just a dream or wish for a better situation to a life that is actually better [7]. The most common emotion here is feeling excited about online teaching's instant personal benefits.

Table 1 The teachers' directions towards their teaching and their initial emotions towards online teaching

\begin{tabular}{|c|c|c|}
\hline Teachers & $\begin{array}{l}\text { The teachers' } \\
\text { directions } \\
\text { towards their } \\
\text { teaching }\end{array}$ & $\begin{array}{l}\text { Initial emotion } \\
\text { towards online- } \\
\text { teaching }\end{array}$ \\
\hline $\begin{array}{l}\text { Bao, 5-year } \\
\text { experience }\end{array}$ & $\begin{array}{l}\text { Teaching as the } \\
\text { most important } \\
\text { task: keeping } \\
\text { students' well- } \\
\text { being improved }\end{array}$ & $\begin{array}{l}\text { Excited to apply } \\
\text { the technological } \\
\text { skills. It attracted } \\
\text { students' } \\
\text { participation. }\end{array}$ \\
\hline $\begin{array}{l}\text { Nha, 6-year } \\
\text { experience }\end{array}$ & $\begin{array}{l}\text { Teaching is the } \\
\text { most important } \\
\text { task: stimulating } \\
\text { his students' } \\
\text { intellectual } \\
\text { development. }\end{array}$ & $\begin{array}{l}\text { Excited and } \\
\text { eager to design; } \\
\text { use the available } \\
\text { computer skills } \\
\text { in lesson } \\
\text { planning. } \\
\text { Students must } \\
\text { like this. }\end{array}$ \\
\hline $\begin{array}{l}\text { Van, 7-year } \\
\text { experience }\end{array}$ & $\begin{array}{l}\text { Teaching as the } \\
\text { most important } \\
\text { task: contact with } \\
\text { students gives } \\
\text { joy. }\end{array}$ & $\begin{array}{l}\text { Feel comfortable } \\
\text { and relaxed } \\
\text { because of the } \\
\text { previous } \\
\text { experience of e- } \\
\text { learning skills. }\end{array}$ \\
\hline $\begin{array}{l}\text { Duc, 8-year } \\
\text { experience }\end{array}$ & $\begin{array}{l}\text { Teaching as the } \\
\text { most important } \\
\text { task: teaching his } \\
\text { subject is the most } \\
\text { important task. }\end{array}$ & $\begin{array}{l}\text { Reluctant and } \\
\text { rather } \\
\text { considerable in } \\
\text { applying } \\
\text { technology in } \\
\text { teaching }\end{array}$ \\
\hline $\begin{array}{l}\text { Hien, 11- } \\
\text { year } \\
\text { experience }\end{array}$ & $\begin{array}{l}\text { Teaching is the } \\
\text { most important } \\
\text { task: } \\
\text { concentrating on } \\
\text { how students feel } \\
\text { and making } \\
\text { students more } \\
\text { complete. }\end{array}$ & $\begin{array}{l}\text { Anxious and } \\
\text { stressed because } \\
\text { not being used to } \\
\text { designing and } \\
\text { teaching online } \\
\text { classes. }\end{array}$ \\
\hline $\begin{array}{l}\text { Liem, } 25- \\
\text { year } \\
\text { experience }\end{array}$ & $\begin{array}{l}\text { Teaching is the } \\
\text { most important } \\
\text { mission: } \\
\text { concentrating on } \\
\text { how students feel } \\
\text { and making } \\
\text { students more } \\
\text { complete. }\end{array}$ & $\begin{array}{l}\text { Prefer blackboard } \\
\text { and face-to-face } \\
\text { teaching. Not self } \\
\text {-confident } \\
\text { enough to teach a } \\
\text { fully online class. }\end{array}$ \\
\hline
\end{tabular}

Regarding Table 1, while these teachers claimed that the emphasis is clearly on the students' well-being and personal growth, due to some private temporary 
convenience, they still found it convenient to teach from home. One participant commented:

It was so great when I can work from home. I did not spend time getting well-dressed and traveling to university. Working with the computer was my favorite, and what I only did was sitting in front of the computer and using the keyboard to guide the students with the various available online programs and software.

Also, online-teaching is believed to help increase students' participation, especially shy students. Two teachers expressed their initial emotion of online-teaching:

“...I am fond of online-teaching because it helps improve communication among students and teachers..."

"...it helps to get the attention of students, they stick more, communicate more, incorporate more, and be more possible for answering teachers' questions..."

A young EFL teacher could have a positive look at language teaching with the help of the internet:

"...Take using a dictionary as an example, when students traditionally want to look up a word, they may open several pages without any ideas of what phonic transcription is. Then they look at the word and see the phonic transaction, which tells you how to pronounce the word, but they are not able to understand. However, if they use an online dictionary, I mean E-dictionary, they can have access to the original word, to the pronunciation of the word with different examples, to the synonym of the word, etc., in a short period of time..."

The other older teacher stated that:

It seemed more convenient for me when I can teach and take care of the housework at the same time. It seems more exciting when I felt more relaxed, especially in the morning, not hurrying children to school and rushing to university.

Students are a significant source of meaningful emotional interactions that teachers have while teaching. The whole community spoke about the passion associated with online-teaching. This is partly due to teaching's volatile nature[23]. Unsurprisingly, more frequently than their seasoned counterparts [15], inexperienced teachers feel excited. Both respondents suggested that their feelings about using online teaching were caused by students' dedication to learning the foreign language. They also claimed that it is assumed that electronic devices lead to increasing the motivation of students in the learning process $[13,14]$.

\subsection{Stage 2: Troubles in Paradise}

The EFL teacher experiences more complex states of mind dominated by confusion at this stage, and the EFL teacher experiences more complex states of mind dominated by confusion and disorientation at this stage, related to what is expected of others and what is expected of the person, as well as a sense of disconnection from one's environment [7]. The emotions reported from feeling restricted (anxious, confused, frustrated), to stress, and then devalued (exhausted).

Five out of six teachers involved noted that there was a lack of control.

" In face-to-face classes, EFL teachers could observe students' mouths when they pronounced, so teachers could adjust students "pronunciation more effectively. Also, students who are sleeping or fading out.

It is easy to recognize students sleeping or fading out in face-to-face class, and then I could adjust my teaching. However, It is different with the online class when students might hide a little bit with technology."

The two oldest participants lacked sufficient knowledge of technology find online-teaching timecosting when they failed to keep on track of the teaching plan and had to learn the technology, which was always in the back of their mind.

".... All the time, you need to be on top of things. At any standard, you should not be ill-prepared to make the class go effectively."

"...I was not effective and skillful with the technology used in the classroom, and some unavoidable technical errors were. So confused...."

"I'd just go online and watch these modules online. Then, before class, I go through those on my own and practice doing it by praying that it works during the class..."

\subsection{Stage 3: The Road to Recovery - Emotion Regulation}

Stage 3 is the combination of Reintegration, Autonomy, and Interdependence in order, which enables a person to adjust the negative feelings and become more aware of and sensitive to the experience of changing teaching platform and methods, which can facilitate professional development [7].

To work on the second research question, "How do EFL teachers regulate their emotions in onlineteaching at Van Lang university?", the researcher went insight into the ways EFL teachers reappraised their negative emotions to keep themselves on track 
with the digitalized trend for a more effective and productive survival in the covid-19 pandemic.

To manage negative emotions or any unexpected challenge aroused during the teaching process, EFL teachers of OLEs are believed to apply reappraisal to breed positive consequences instead of suppression, which can result in negative consequences [12].

When their students understood what was taught and made progress in their development (Liem, Duc, Hien), when their students followed class rules and policies (Nha, Van), or when they received supportive and collaborative support from the institutions and their colleagues, the six EFL teachers in the study gained happiness and satisfaction (Table 2). Another positive emotion that teachers often felt was pride when they could manage to work well with the online-teaching system with fewer obstacles (Liem, Duc, Hien). Finally, they all felt proud when they achieved workrelated goals.

"...Regarding the benefits of technology and online-teaching, I am more excited and ready to continue using online-teaching technology... "'is-p.'..., I will continue to teach online because for me it facilitates learning and teaching as well..."

“...Obviously, online-teaching widened a huge world for exploring teaching methods and strategies. As long as it got improved, I keep on doing more research and studying with it..."

“... I am a facilitator with online-teaching so that the changes of my role in teaching affect my emotions in the way I traditionally consider my

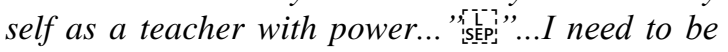
like an up-to-date person, a new me, I am following up to date tendency, popular technology devices, I need to seem like a role module for my students..."

Online-teaching brought me the feeling of being another learner. I will never stop learning, and it makes me a better teacher. That's how I think it contributes to my emotional balance. I think this is one of the key roles of technology, and it helps me in reshaping my emotion..."

Table 2 The teachers' directions towards the school organizational aspects of their work.

\begin{tabular}{|l|l|}
\hline Teachers & $\begin{array}{l}\text { The teachers' directions towards the } \\
\text { school organizational aspects of } \\
\text { their work. }\end{array}$ \\
\hline $\begin{array}{l}\text { Bao, 5-year } \\
\text { experience }\end{array}$ & $\begin{array}{l}\text { Keep constant contact with teachers } \\
\text { for support. } \\
\text { The flexible teaching time is applied } \\
\text { (two-thirds of teaching time is allowed } \\
\text { for online-teaching) }\end{array}$ \\
\hline
\end{tabular}

\begin{tabular}{|l|l|}
\hline $\begin{array}{l}\text { Nha, 6-year } \\
\text { experience }\end{array}$ & $\begin{array}{l}\text { Regular online meeting for guiding or } \\
\text { problem-solving. } \\
\text { The technology service staffs are very } \\
\text { helpful. }\end{array}$ \\
\hline $\begin{array}{l}\text { Van, 7-year } \\
\text { experience }\end{array}$ & $\begin{array}{l}\text { She highly appreciated the staff's } \\
\text { effective collaboration to help the } \\
\text { online teaching and learning } \\
\text { productive. }\end{array}$ \\
\hline $\begin{array}{l}\text { Duc, 8-year } \\
\text { experience }\end{array}$ & $\begin{array}{l}\text { He was interested in the trendy } \\
\text { application of digitalization into } \\
\text { academic and managerial activities. }\end{array}$ \\
\hline $\begin{array}{l}\text { Hien, 11- } \\
\text { year } \\
\text { experience }\end{array}$ & $\begin{array}{l}\text { The helpful and mutual support from } \\
\text { colleagues brought him beliefs and } \\
\text { efficacy for his effective online- } \\
\text { teaching }\end{array}$ \\
\hline $\begin{array}{l}\text { Liem, 25- } \\
\text { year } \\
\text { experience }\end{array}$ & $\begin{array}{l}\text { The institution has widened its } \\
\text { relationship with the national and } \\
\text { international organizations for } \\
\text { workshops and talk shows. }\end{array}$ \\
\hline
\end{tabular}

Shin and Lee [30] argued that "online education is the single major development and logical long-term strategy for teacher preparedness, providing flexibility and convenience by providing anyone, anytime, anywhere, with learning opportunities."

\section{CONCLUSION}

As a reflective measure to criticize teaching practices in OLEs, this study's method was carried out. Using the qualitative method, the participants first considered their own teaching in a 10-week semester, first introducing online teaching, then shared how they felt about particular circumstances. Finally, the shifting attitudes were understood, and they revealed themselves as teachers in order to control these feelings and emotions in OLEs. The researcher assumes that this study can inform the current needs of EFL teachers at Van Lang University for teaching in OLEs and other schools of education that train teachers to work in OLEs and/or administrators who can design programs to support their staff and/or students. An important first-step solution could be to continue the conversation between EFL instructors about developing OLEs as a community of practice; an opportunity to share experiences, exchange strategies, and gain help from each other to proactively manage emotions and to better understand the process of teaching and learning in online environments. Therefore, future research might be conducted with different participants of various ages and teaching experiences to have the results more generalizable. 


\section{REFERENCES}

[1] Badia, A., Meneses, J., \& Monereo, C. Affective dimension of university professors about their teaching: An exploration through the semantic differential technique. Universitas Psychologica, 13, (2014) 161-173.

[2] Barcelos, A. M. F., \& Ruohotie-Lyhty, M. Teachers' emotions and beliefs in second language teaching: Implications for teacher education. In Emotions in Second Language Teaching Springer, Cham. (2018) 109-124.

[3] Bengtsson M. How to plan and perform a qualitative study using content analysis. Journal of Nursing Plus Open. 2 (2016) 8-14. https://doi.org/10.1016/j.npls. 2016.01.001

[4] Bernard, R. M., Abrami, P. C., Lou, Y., Borokhovski, E., Wade, A., Wozney, L., et al. How does distance education compare with classroom instructions? A meta- analysis of the empirical literature. Retrieved from. Review of Educational Research, 74(3) (2006), 379-439 http://rer.sagepub.com/

[5] Bohnstedt, K. Instructor interaction and immediacy behaviors in a multipoint videoconferenced instructional environment: A descriptive case study. (Doctoral dissertation). Available from Digital Dissertations. (Publication No. AAT 3452424) (2011)

[6] Cowie, N. Emotions that experienced English as a foreign language (EFL) teachers feel about their students, their colleagues and their work. Teaching and Teacher Education, 27(1) (2011) 235-242.

[7] Cupsa, I. Culture shock and identity. Transactional Analysis Journal, 48(2) (2018) 181-191.

[8] Fried, L. Teaching teachers about emotion regulation in the classroom. Australian Journal of Teacher Education (Online), 36(3) (2011).

[9] Gross, J. J., Emotion regulation: Affective, cognitive, and social consequences. Psychoptysiology, 39 (2002) 281-291.

[10] Gross, J.J., \& John, O.P., Individual differences in two emotion regulation processes: Implications for affect, relationships, and wellbeing. Journal of Personality and Social Psychology, 85 (2003) 348-362.

[11] Gross, J.J., \& Thompson, R.A., Emotion regulation: Conceptual foundations. In J.J. Gross (Ed.), Handbook of Emotion Regulation. New York: Guildford Press (2006).

[12] Gross, J.J., Emotion regulation. In M. Lewis, J. M. Haviland-Jones \& L. F. Barrett (Eds.), Handbook of emotions (3rd ed.) New York, NY: Guilford. (2008) 497-512

[13] Habibi A, Mukminin A, Riyanto Y, Prasojo L, Sulistiyo
Building an online community: Student teachers' perception on the advantages of using social networking services in a teacher education program. Turkish Online Journal in

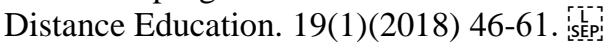

[14] Heafner T. Using technology to motivate students to learn social studies. Contemporary Issues in Technology and Teacher Education. 4(1) (2004) 42-53. "istepi

[15] Huberman, M. The lives of teachers. London, NewYork: Cassell and Teachers College Press. (1993).

[16] International Association of Universities. Covid-19: Higher education challenges and responses. International Association of Universities. https://www.iau-aiu.net/Covid19- , (2020).

[17] Jacobs, S. E., \& Gross, J. J., Emotion regulation in education. International handbook of emotions in education, (2014) 183-217.

[18] Krueger, R. A., \& Casey, M. A. Focus groups: A practical guide for applied research (4th ed.). Thousand Oaks, CA: Sage.

[19] Löfström, E., \& Nevgi, A. Giving shape and form to emotion: Using drawings to identify emotions in university teaching. International Journal for Academic Development, 19(2) (2013) 99-111.

[20] MacFadden, R. J. Souls on ice: Incorporating emotion in web-based education. Retrieved from. Journal of Education in Human Services, 23(1/2) (2005) 79-98 http:// innovateonline.info/

[21] Melnick, S.M., \& Hinshaw, S.P. Emotion regulation and parenting in $\mathrm{AD} / \mathrm{HD}$ and comparison boys: Linkages with social behaviours and peer preference. Journal of Abnormal Child Psychology, 28 (2000) 73-86

[22] MOET. The information and communications going along with education and training in the preventing Covid-19. (Publication No. 02/04/2020)

https://en.moet.gov.vn/news/Pages/ events.aspx?ItemID=3933, (2020).

[23] Nias, J. Primary teachers talking: A study of teaching as work. Routledge. (1989).

[24] Pavlenko, A. The affective turn in SLA: From 'affective factors' to 'language desire' and 'commodification of affect'. In D. GabryśBarker \& J. Bielska (Eds.), The affective dimension in second language acquisition (pp. 3-28). Bristol: Multilingual Matters. (2013).

[25] Regan, K., Evmenova, A., Baker, P., Jerome, M. K., Spencer, V., Lawson, H., \& Werner, T. Experiences of instructors in online learning environments: Identifying and regulating emotions. The Internet and Higher Education, 15(3)(2012) 204-212.

[26] Reupert, A., Maybery, D., Patrick, K., \& 
Chittleborough, P. The importance of being human: Instructors' personal presence in distance programs. Retrieved from. International Journal of Teaching and Learning in Higher Education, http://www.isetl.org/ijtlhe/ 21(1) (2009) 47-56

[27] Santilli, S., \& Beck, V. Graduate faculty perceptions of online teaching. The Quarterly Review of Distance Education, 6 (2005) 155-

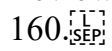

[28] Scherer, K. R. What are emotions? And how can they be measured?. Social science information, 44(4)(2005) 695-729.

[29] Seok, S. Teaching aspects of e-learning. Retrieved from. International Journal on ELearning,http://www.aace.org/pubs/ijel/ 7(4) (2008) 725-741

[30] Shin, M., \& Lee, Y. J. Changing the landscape of teacher education via online teaching and learning. Retrieved from www.Acteonline.org (2009).

[31] Smith, S. J., \& Meyen, E. L. Applications of online instruction: An overview for teachers, students with mild disabilities, and their parents. Focus on Exceptional Children, http://findarticles.com/p/articles/mi_qa3813/ Retrieved from 35(6)(2003) 1-15

[32] Song, J. Emotions and language teacher identity: Conflicts, vulnerability, and transformation. TESOL quarterly, 50(3) (2016) 631-654.

[33] Sutton, R. E., \& Harper, E. Teachers' emotion regulation. In International handbook of research on teachers and teaching. Springer, Boston, MA. (2009) 389-401.
[34] Trigwell, K. Relations between teachers' emotions in teaching and their approaches to teaching in higher education. Instructional

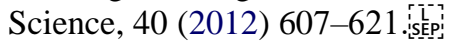

[35] Wallace, R. M. Online learning in higher education: A review of the research on interactions among teachers and students. Education, Communication \& Informa- tion, doi:10.1080/14636310303143, 3(2)(2003) 241-280,

[36] Wexler, P. Chaos and cosmos: educational discourse and social change. Journal of Curriculum Studies, 34(4) (2002) 469-479.

[37] Wickersham, L. E., \& McElhany, J. A. Bridging the divide: Reconciling administrator and faculty concerns regarding online education. The Quarterly Review of Distance Education, 11 (2010) 1-12.

[38] Wolff, D., \& De Costa, P. I. Expanding the language teacher identity landscape: An investigation of the emotions and strategies of a NNEST. The Modern Language Journal, 101(S1), (2017) 76-90.

[39] Young, A., \& Norgard, C. Assessing the quality of online courses from students' perspective. Internet and Higher Education,doi:10.1016/j.iheduc.2006.03.001. 9(2) (2006) 107-115.

[40] Zembylas, M., Theodorou, M., \& Pavlakis, A. The role of emotions in the experience of online learning: Challenges and opportunities. Educational Media International,doi:10.1080/09523980802107237, 45(2) (2008) 107-117, 